\title{
PERBANDINGAN PREDIKSI KEBANGKRUTAN MENGGUNAKAN MODEL ALTMAN MODIFIKASI, SPRINGATE, ZMIJEWSKI DAN GROVER PT RATU PRABU ENERGI TBK
}

\author{
Budhi Suparningsih, ${ }^{1)}$ \\ 1) Dosen Program Studi Manajemen FE UNKRIS \\ Email : budhiunkris@gmail.com \\ Ella Siti Chaeriah ${ }^{2)}$ \\ 2) Dosen Program Studi Manajemen FE UNKRIS \\ Alamat: Kampus UNKRIS, Jatiwaringin Jakarta Timur \\ Email : Ellasitichaeriah@gmail.com
}

\begin{abstract}
This study examines comparative analysis to predict bankruptcy using the modified Altman, Springate, Zmijewski and Grover models at PT. Ratu Prabu Energi, Tbk. which is engaged in the mining sector. This study aims to predict bankruptcy at PT. Ratu Prabu Energi, Tbk. and to evaluate whether the predictions match the actual conditions of the company. The type of research applied is a case study at PT. Ratu Prabu Energi, Tbk. during 2009 until 2018. Data were analyzed using qualitative descriptive analysis techniques. The results of the analysis of the four bankruptcy models have different results, although there are some in the position of the Safe Zone but the value is very small and almost close to the Distress Zone, so the company seems to have unfavorable financial conditions as indicated by the low weighting value of the four bankruptcy models. From the beginning this condition has been seen from the ratios represented in each bankruptcy model. Of the four bankruptcy models, this gives a fairly high value deviation in the Altman Z-Score Modification model rather than using the Springate, Zmijewski and Grofer bankruptcy models.
\end{abstract}

Keywords: predict bankruptcy, Model Altman, Springate, Zmijewski, Grover

\section{PENDAHULUAN}

Gejolak ekonomi global membuat pengusaha di sektor pertambangan di dalam negeri mengeluh. Pasalnya, dinamika perekonomian global berimbas pada kondisi domestik, mulai dari krisis finansial global di tahun 2008 hingga 2009 lalu pertengahan tahun 2014 harga minyak dunia mulai ada penurunan tajam yang disebabkan oleh perlambatan aktivitas perekonomian dunia, peningkatan produksi minyak di Amerika Serikat, lalu diperparah dengan kebijakan untuk tidak mengurangi tingkat produksi minyak oleh Organization Of Petroleum Exporting Countries. Selama periode tigabelas tahun harga minyak dunia menyentuh titik terendah di awal tahun 2016. Gejolak perekonomian global ini menciptakan peningkatan biaya produksi dan operasional pada perusahaan yang bergerak di sektor migas.

Kurangnya eksplorasi dan investasi pada sektor pertambangan merupakan penyebab penurunan produksi minyak mentah di Indonesia dan terhambatnya pertumbuhan pendapatan domestik bruto, target produksi minyak yang ditetapkan oleh pemerintah pada awal tahun selalu tidak tercapai dikarenakan produksi minyak dihasilkan dari ladang minyak yang sudah lama. Punyulingan minyak yang terdapat di Indonesia memiliki daya 
tampung sama dengan satu dekade yang lalu, ini mengindikasikan adanya keterbatasan perkembangan pada produksi minyak dan akhirnya menyebabkan negara mengimpor minyak agar dapat memenuhi kebutuhan domestik.

Bank Indonesia mendorong untuk menerbitkan peraturan kepada masyarakat indonesia dalam bertransaksi perdagangan agar mewajibkan masyarakat indonesia menggunakan rupiah saat bertransaksi didalam negeri, kewajiban ini diakibatkan adanya pelemahan nilai tukar rupiah terhadap dolar, sementara itu perjanjian kontrak kerja antara perusahaan SKK migas dan perusahaan penunjang migas yang sudah berlangsung menggunakan mata uang dolar harus di amendemen menjadi mata uang rupiah disetiap transaksinya, amendemen perubahan kontrak kerja ini mempengaruhi peningkatan biaya operasional mengingat bahan baku seperti consumables atau barang yang habis pakai, equipment atau alat-alat yang digunakan, chemical atau bahan kimia yang dimanfaatkan dalam produksi migas masih diimpor dari luar dan pembelian barangnya harus menggunakan dolar, sedangkan Indonesia sendiri belum mampu memproduksi bahan-bahan berkualitas untuk peralatan maupun perlengkapan dalam memproduksi migas, secara produksi migas merupakan produksi yang memiliki resiko tinggi jadi membutuhkan peralatan maupun perlengkapan yang berkualitas dan berstandar internasional.

Manajemen yang lemah dari pemerintah mengenai sektor pertambangan, dimulai dari sistem pemerintah yang banyak lika-likunya, peraturan yang tidak jelas dan berubahubah setiap masa, hal ini menimbulkan iklim investasi yang tidak menarik bagi investor karena berinvestasi pada perusahaan minyak membutuhkan waktu yang panjang maupun biaya yang mahal.
Pemerintah Indonesia berkomitmen agar dapat menciptakan suasana yang kondusif pada sektor pertambangan demi menjaga pasokan dalam negeri akan tetapi gejolak ekonomi dunia berupa penurunan harga minyak yang menimbulkan pengaruh langsung terhadap penurunan aliran investasi pada sektor pertambangan dalam negeri. Keadaan inilah yang dapat menyebabkan perusahaan di sektor migas mengalami kesulitan keuangan (financial distress) dan diprediksi akan bangrut.

Menurut Plat dalam Fahmi (2013), "Financial Distress adalah sebagai tahap penurunan kondisi keuangan yang terjadi sebelum terjadinya kebangkrutan ataupun likuidasi. Financial distress dimulai dengan ketidak mampuan memenuhi kewajiban-kewajibannya terutama kewajiban yang bersifat jangka pendek termasuk kewajiban likuiditas dan juga termasuk kewajiban dalam kategori solvabilitas".

Risiko kebangkrutan pada perusahaan dapat dilihat dan diukur melalui laporan keuangan dengan melakukan analisis rasio terhadap laporan keuangan perusahaan yang bersangkutan. Secara umum, faktor penentu kebangkrutan dan kesulitan keuangan dapat dibagi menjadi empat kelompok utama rasio keuangan yaitu rasio manajemen aset, rasio leverage, rasio likuiditas dan rasio profitabilitas. Maka untuk mengatasi dan meminimalisir terjadinya kebangkrutan, perusahaan dapat mengawasi kondisi keuangan dengan menggunakan teknik-teknik analisis laporan keuangan. Analisis laporan keuangan merupakan alat yang penting untuk memperoleh informasi yang berkaitan dengan posisi keuangan perusahaan serta hasil yang telah dicapai berhubungan dengan pemilihan strategi perusahaan yang telah diterapkan. Dengan melakukan analisis laporan keuangan perusahaan, maka dapat diketahui kondisi dan perkembangan 
financial perusahaan. Selain itu, juga dapat diketahui kelemahan serta hasil yang dianggap cukup baik dan potensi kebangkrutan perusahaan.

Berdasarkan latar belakang diatas penelitian ini bertujuan untuk mengetahui perbandingan antara model-model prediksi kebangkrutan perusahaan dan menjelaskan prediksi kebangkrutan pada PT Ratu Prabu Energi Tbk yang bergerak pada sektor migas yang terdaftar di Bursa Efek Indonesia. Model prediksi yang digunakan adalah model Altman modifikasi, springate, zmijewski dan grover.

\section{LANDASAN TEORI}

\section{Financial Distress dan Kebangkrutan}

Menurut Hanafi (2007), "Financial distress dapat digambarkan dari dua titik ekstrem yaitu kesulitan likuiditas jangka pendek sampai insolvable. Kesulitan keuangan jangka pendek biasanya bersifat jangka pendek, tetapi bisa berkembang menjadi parah. Indikator kesulitan keuangan dapat dilihat dari analisis aliran kas, analisis strategi perusahaan dan laporan keuangan perusahaan". Sedangkan kebangkrutan menurut Karina (2014), "merupakan kondisi dimana perusahaan tidak mampu lagi untuk melunasi kewajibannya. Kondisi ini biasanya tidak muncul begitu saja di perusahaan, ada indikasi awal dari perusahaan tersebut yang biasanya dapat dikenali lebih dini kalau laporan keuangan dianalisis secara lebih cermat dengan suatu cara tertentu."

Berdasarkan kedua pengertian di atas dapat disimpulkan bahwa kesulitan keuangan adalah suatu situasi dimana arus kas operasi perusahaan tidak memadai untuk melunasi kewajibankewajiban lancar (seperti hutang dagang atau beban bunga) dan perusahaan terpaksa melakukan tindakan perbaikan. Dan kesulitan keuangan adalah masalah likuiditas yang sangat parah yang tidak bisa dipecahkan tanpa perubahan ukuran dari operasi atau struktur perusahaan. Informasi financial distress ini dapat dijadikan sebagai peringatan dini atas kebangkrutan sehingga menajemen dapat melakukan tindakan secara cepat untuk mencegah masalah sebelum terjadinya kebangkrutan.

Kebangkrutan suatu perusahaan ditandai dengan financial distress, yaitu keadaan dimana perusahaan lemah dalam menghasilkan laba atau perusahaan cenderung mengalami defisit. Dengan kata lain, kebangkrutan dapat diartikan sebagai kegagalan perusahaan dalam menjalankan operasi perusahaan untuk memperoleh laba. Kebangkrutan juga sering disebut likuidasi perusahaan atau penutupan perusahaan atau insolvensi. "Kebangkrutan sebagai kegagalan diartikan sebagai kegagalan keuangan atau financial failure dan kegagalan ekonomi atau economic failure." Adnan dan Kurniasih (2000).

Kegagalan dalam arti ekonomi merupakan keadaan dimana perusahaan kehilangan uang atau pendapatan perusahaan tidak bisa menutupi biayanya sendiri. Ini berarti bahwa nilai sekarang dari arus kas sebenarnya lebih kecil dari kewajiban atau laba lebih kecil dari modal kerja. Kegagalan terjadi bila arus kas yang sebenarnya dari perusahaan tersebut jauh di bawah arus kas yang diharapkan. Bahkan, kegagalan juga bisa berarti bahwa tingkat pendapatan dari biaya historis atau investasinya lebih kecil daripada biaya modal perusahaan.

Kegagalan keuangan bisa diartikan sebagai insolvensi yang membedakan antara arus kas dan dasar saham. Insolvensi atas dasar arus kas ada dua bentuk yaitu insolvensi teknik dan insolvensi dalam pengertian kebangkrutan. Insolvensi teknik merupakaan keadaan dimana perusahaan dianggap tidak dapat memenuhi kewajibannya pada saat jatuh tempo. Walaupun total aktiva melebihi total 
utang atau terjadi bila suatu perusahaan gagal memenuhi salah satu atau lebih kondisi dalam ketentuan hutangnya seperti rasio aktiva lancar terhadap kewajiban lancar yang telah ditetapkan atau total kekayaan bersih terhadap total aktiva yang disyaratkan. Insolvensi teknik juga terjadi bila arus kas tidak cukup untuk memenuhi pembayaran pokok pada tanggal tertentu. Insolvensi dalam pengertian kebangkrutan didefenisikan dalam ukuran sebagai kekayaan bersih negatif dalam neraca konvensional atau nilai sekarang dari arus kas yang diharapkan lebih kecil dari kewajiban.

Kebangkrutan dapat disimpulkan sebagai suatu keadaan atau situasi dalam hal ini perusahaan gagal atau tidak mampu lagi memenuhi kewajibankewajiban kepada debitur karena perusahaan mengalami kekurangan dan ketidakcukupan dana untuk menjalankan atau melanjutkan usahanya sehingga tujuan ekonomi yang ingin dicapai oleh perusahaan tidak dapat dicapai yaitu profit, sebab dengan laba yang diperoleh perusahaan bisa digunakan untuk mengembalikan pinjaman, membiayai operasi perusahan dan kewajibankewajiban yang harus dipenuhi bisa ditutup dengan laba atau aktiva yang dimiliki. Salah satu dampak dari kebangkrutan ini adalah terjadinya pengurangan karyawan dalam jumlah besar pada beberapa periode waktu sebagai suatu kebijakan untuk mengurangi biaya operasi perusahaan dan banyaknya kegiatan operasional yang vakum.

\section{Model Prediksi Kebangkrutan}

Menurut Manula, Octavianus dan Kalmadara (2017), "Resiko kebangkrutan pada perusahaan dapat dilihat dan diukur melalui laporan keuangan dengan melakukan analisis rasio terhadap laporan keuangan yang dikeluarkan oleh perusahaan yang bersangkutan". Menurut
Alifiah (2013), "Secara umum, faktor penentu kebangkrutan dan kesulitan keuangan dapat dibagi menjadi empat kelompok utama rasio keuangan yaitu rasio manajemen aset, rasio leverage, rasio likuiditas dan rasio profitabilitas".

$$
\text { Untuk mengatasi dan }
$$

meminimalisir terjadinya kebangkrutan, perusahaan dapat mengawasi kondisi keuangan dengan menggunakan teknikteknin analisis laporan keuangan. Analisis laporan keuangan merupakan alat yang penting untuk memperoleh informasi yang berkaitan dengan posisi keuangan perusahaan serta hasil yang telah dicapai sehubungan dengan pemilihan strategi perusahaan yang telah diterapkan. Dengan melakukan analisis laporan keuangan perusahaan, maka dapat diketahui kondisi dan perkembangan financial perusahaan. Selain itu juga dapat diketahui kelemahan serta hasil yang dianggap cukup baik dan potensi kebangkrutan perusahaan tersebut.

\section{Model Springate}

Model ini dikembangkan oleh Springate (1978) dengan menggunakan analisi multidiskriminan dengan menggunakan empat puluh perusahaan sebagia sampelnya. Model ini dapat digunakan untuk memprediksi kebangkrutan dengan tingkat keakuratan 95,5\%. Model yang berhasil dikembangkan oleh Springet adalah:

$\mathrm{Z}=1,03 \mathrm{~A}+3,07 \mathrm{~B}+0,66 \mathrm{C}+0,4 \mathrm{D}$

Notasi:

$\mathrm{A}=$ Working Capital $/$ Total Asset

$\mathrm{B}=$ Net Profit Before Interest And Taxes

/ Total Asset

$\mathrm{C}=$ Net Profit Before Taxes / Current

Liabilities

$\mathrm{D}=$ Sales $/$ Total Asset

Jika $\mathrm{Z}<0,862$ maka perusahaan diklasifikasikan "Failed" 


\section{Model Zmijewski}

Model

Zmijewski

(1984)

menggunakan analisis rasio yang mengukur kinerja, leverage dan likuiditas suatu perusahaan untuk model prediksi. Zmijewski menggunakan probit analisis yang diterapkan pada empat puluh perusahaan yang telah bangkrut dan 800 perusahaan yang masih bertahan pada saat itu. Model yang berhasil dikembangkan adalah sebagai berikut:

$X=-4,3-4,5 X_{1}-5,7 X_{2}-0,04 X_{3}$

Notasi:

$\mathrm{X}_{1}=\mathrm{ROA}$ (Return On Asset)

$\mathrm{X}_{2}=$ Leverage (Debt Ratio $)$

$\mathrm{X}_{3}=$ Likuiditas (Current Ratio)

Jika $X>0$ maka perusahaan diklasifikasikan mengalami Financial Distress sedangkan jika $\mathrm{X}<0$ maka perusahaan diklasifikasikan tidak mengalami Financial Distress.

\section{Model Altman Z-Score}

Model Altman Pertama

Rumusan ini dihasilkan dari penelitian atas berbagai perusahaan manufaktur di Amerika Serikat yang menjual sahamnya di bursa efek. Karena itu rumusan tersebut lebih cocok digunakan untuk memprediksi keberlangsungan usaha perusahaanperusahaan manufaktur yang Go Public. Setelah melakukan penelitian terhadap variabel dan sampel yang dipilih, Altman menghasilkan model kebangkrutan yang pertama. Persamaan kebangkrutan yang ditunjukkan untuk memprediksi sebuah perusahaan publik manufaktur.

Persamaan dari model Altman pertama yaitu:

$\mathrm{Z}=1,2 \mathrm{X}_{1}+1,4 \mathrm{X}_{2}+3,3 \mathrm{X}_{3}+0,6 \mathrm{X}_{4}+$ $0,999 X_{5}$

Keterangan:

$\mathrm{Z}=$ Bankrupcy Index

$\mathrm{X}_{1}=$ Working Capital / Total Asset

$\mathrm{X}_{2}=$ Retained Earnings / Total Asset

$\mathrm{X}_{3}=$ Earning Before Interest And Taxes /

Total Asset
$\mathrm{X}_{4}=$ Market Value Of Equity / Book
Value Of Total Debt

$\mathrm{X}_{5}=$ Sales $/$ Total Asset

Jika nilai $\mathrm{Z}<1,8$ maka termasuk perusahaan yang bangkrut, jika nilai 1,8 $<\mathrm{Z}<2,99$ maka termasuk grey area atau tidak dapat ditentukan apakah perusahaan sehat ataupun mengalami kebangkrutan dan jika nilai $\mathrm{Z}>2,99$ maka termasuk perusahaan yang tidak bangkrut.

\section{Model Altman Revisi}

Untuk perusahaan privat yang tidak mempunyai nilai pasar, maka Altman mengembangkan model Alternatif dengan menggantikan variabel $\mathrm{X}_{4}$ yang semula merupakan perbandingan Market Value Of Equity To Book Value Of Total Debt menjadi perbandingan Book Value Of Equity To Book Value Of Total Debt". $Z^{\prime}=0,717 \mathrm{X}_{1}+0,847 \mathrm{X}_{2}+3,108 \mathrm{X}_{3}+$ $0,42 \mathrm{X}_{4}+0,988 \mathrm{X}_{5}$

Keterangan:

Z' = Bankrupcy Index

$\mathrm{X}_{1}=$ Working Capital / Total Asset

$\mathrm{X}_{2}=$ Retained Earnings / Total Asset

$\mathrm{X}_{3}=$ Earning Before Interest And Taxes / Total Asset

$\mathrm{X}_{4}=$ Book Value Of Equity / Book Value Of Total Debt

$\mathrm{X}_{5}=$ Sales $/$ Total Asset

Jika nilai $Z^{\prime}<1,23$ maka termasuk perusahaan yang bangkrut, jika nilai 1,23 $<$ Z' $<2,9$ maka termasuk grey area atau tidak dapat ditentukan apakah perusahaan sehat ataupun mengalami kebangkrutan, jika nilai $Z^{\prime}>2,9$ maka termasuk perusahaan yang tidak bangkrut.

Model Altman Modifikasi

Altman kembali melakukan penelitian di Mexico yaitu negara yang sedang berkembang dengan harapan bahwa rumusan Z-Score dapat digunakan dalam perusahaan Go Public dan Non Go Public. Setelah melakukan penelitian dengan objek berbagai perusahaan manufaktur dan menghasilkan dua rumus pendeteksi kebangkrutan, Altman 
melakukan penelitian lagi mengenai potensi kebangkrutan perusahaanperusahaan selain perusahaan manufaktur, baik yang Go Public maupun yang tidak. Rumusan Z-Score terakhir merupakan rumus yang sangat fleksibel karena bisa digunakan untuk berbagai jenis bidang perusahaan baik yang Go Public maupun yang tidak dan cocok digunakan di negara berkembang seperti Indonesia.

Seiring dengan berjalannya waktu dan penyesuaian terhadap berbagai jenis perusahaan. Altman kemudian memodifikasi modelnya supaya dapat diterapkan pada semua perusahaan, seperti manufaktur, non manufaktur dan perusahaan penerbit obligasi di negara berkembang (Emerging Market). Dalam Z-Score modifikasi ini Altman mengeliminasi variabel X5 yaitu Sales To Total Asset. Karena rasio ini sangat bervariatif pada industri dengan ukuran asset yang berbeda-beda. Berikut persamaan Z-Score yang di modifikasi Altman dan kawan-kawan (1995):

$Z "=6,56 X_{1}+3,26 X_{2}+6,72 X_{3}+1,05 X_{4}$

Z" = Bankrupcy Index

$\mathrm{X}_{1}=$ Working Capital / Total Asset

$\mathrm{X}_{2}=$ Retained Earnings / Total Asset

$\mathrm{X}_{3}=$ Earning Before Interest And Taxes /

Total Asset

$\mathrm{X}_{4}=$ Book Value Of Equity / Book Value Of Total Debt

Klasifikasi perusahaan yang sehat dan bangkrut didasarkan pada nilai ZScore model Altman modifikasi yaitu jika nilai Z" $<1,1$ maka termasuk perusahaan yang bangkrut, jika nilai $1,1<\mathrm{Z}$ " $<2,6$ maka termasuk grey area atau tidak dapat ditentukan apakah perusahaan sehat ataupun mengalami kebangkrutan, jika nilai Z" > 2,6 maka termasuk perusahaan yang tidak bangkrut.

\section{Model Grover}

Model Grover merupakan model yang diciptakan dengan melakukan pendesainan dan penelitian ulang terhadap model Altman Z- Score. Jeffrey S. Grover menggunakan sampel sesuai dengan Z-Score pada tahun 1968 dengan menambahkan 13 rasio keuangan baru. Sampel yang digunakan sebanyak 70 perusahaan dengan 35 perusahaan yang bangkrut dan 35 perusahaan yang tidak bangkrut pada tahun 1982 sampai 1996. Grover (2001) dalam Prihanthini (2013) menghasilkan persamaan sebagai berikut :

G-Score $=1,650 \mathrm{X}_{1}+3,404 \mathrm{X}_{2}-$ $0,016 \mathrm{ROA}+0,057$

Keterangan :

$\mathrm{X}_{1}=$ Working Capital $/$ Total Assets

$\mathrm{X}_{2}=$ Earning before interest and taxes /

Total Assets

ROA = Net Income $/$ Total Assets

Model Grover mengkategorikan perusahaan dalam keadaan bangkrut dengan skor kurang atau sama dengan $0,02(\mathrm{G} \leq-0,02)$ sedangkan nilai untuk perusahaan yang dikategorikan dalam keadaan tidak bangkrut adalah lebih atau sama dengan $0,01(\mathrm{G} \geq 0,01)$. Perusahaan dengan skor di antara atas dan bawah berada pada grey area.

\section{METODE PENELITIAN}

Penelitian ini merupakan penelitian deskriptif kualitatif. Format desain deskriptif kualitatif banyak memiliki kesamaan dengan desain deskriptif kuantitatif, karena itu desain deskriptif kualitatif bisa disebut pula dengan kuasi kualitatif atau desain kualitatif semu. Yang artinya, desain ini belum benarbenar kualitatif karena bentuknya masih dipengaruhi oleh tradisi kuantitatif, terutama dalam menempatkan teori pada data yang diperolehnya.

Tujuan penelitian deskriptif ini adalah untuk menjelaskan empat model prediksi financial distress dan menganalisis titik cut off dari setiap model prediksi kebangkrutan. Model prediksi kebangkrutan yang digunakan dalam penelitian ini adalah model 
Springate, Zmijewski, Altman Modifikasi dan Grover.

Dalam penelitian ini populasinya adalah laporan keuangan tahunan PT. Ratu Prabu Energi Tbk. yang bergerak pada sektor migas yang terdaftar dalam IDX (Bursa Efek Indonesia). Teknik pengambilan sampling yang digunakan adalah purposive sampling yaitu pertimbangan peneliti dalam menentukan sampel didasarkan pada kriteria khusus yaitu perusahaan yang memiliki laporan keuangan yang lengkap dan telah menerbitkan laporan keuangan sembilan tahun secara berturut-turut dalam periode pengamatan. Dalam penelitian ini sampel yang diambil oleh peneliti adalah laporan keuangan tahunan PT. Ratu Prabu Energi Tbk. periode 2009 sampai dengan 2018.

\section{HASIL PENELITIAN DAN PEMBAHASAN}

\section{Model Altman Z-Score Modifikasi}

Data finansial pada Tabel-1. diambil dari laporan keuangan tahunan PT. Ratu Prabu Energi, Tbk. periode 2009 sampai dengan 2018 yang disampaikan dalam mata uang rupiah, untuk membentuk variabel nilai Z-Score modifikasi terdiri dari Working Capital, Total Asset, Retained Earning, Earning Before Interest And Taxes, Book Value Of Equity dan Book Value Of Total Debt.

\section{Tabel-1. Data Finansial Pembentuk Variabel Nilai Z-Score} Selama Periode 2009-2018

\begin{tabular}{lrrrrrrrrrr}
\hline \multirow{2}{*}{\begin{tabular}{l} 
DESCRIP \\
\multicolumn{1}{c}{ TION }
\end{tabular}} & $\mathbf{2 0 0 9}$ & $\mathbf{2 0 1 0}$ & $\mathbf{2 0 1 1}$ & $\mathbf{2 0 1 2}$ & $\mathbf{2 0 1 3}$ & $\mathbf{2 0 1 4}$ & $\mathbf{2 0 1 5}$ & $\mathbf{2 0 1 6}$ & $\mathbf{2 0 1 7}$ & $\mathbf{2 0 1 8}$ \\
\hline $\begin{array}{l}\text { Working } \\
\text { Capital }\end{array}$ & 198.788 & 103.031 & 136.399 & 105.901 & 335.841 & 253.457 & 600.291 & 570.495 & 512.271 & 445.502 \\
$\begin{array}{l}\text { Total } \\
\text { Asset }\end{array}$ & 1.406 .978 & 1.367 .942 & 1.453 .141 & 1.432 .284 & 1.596 .735 & 1.810 .441 & 2.487 .618 & 2.656 .070 & 2.506 .050 & 2.692 .456 \\
Retained & & & & & & & & & & \\
Earning & - & -269.786 & 258.021 & -228.601 & -154.568 & -12.991 & -118.687 & -114.286 & -104.175 & -104.175 \\
EBIT & 66.763 & 30.699 & 30.120 & 75.151 & 177.804 & 91.161 & 63.997 & 48.875 & 98.206 & 107.670 \\
BVE & 763.685 & 794.290 & 803.063 & 855.759 & 927.916 & 967.413 & 1.686 .021 & 1.731 .149 & 1.760 .159 & 1.793 .023 \\
BVL & 642.716 & 572.653 & 650.033 & 576.480 & 649.515 & 806.258 & 763.272 & 885.647 & 745.890 & 899.433 \\
\hline
\end{tabular}

Variabel nilai Z-Score merupakan rasio-rasio keuangan yang menunjukkan kondisi keungan perusahaan, variabel $\mathrm{X}^{1}$ merupakan hasil dari nilai Working Capital dibagi Total Asset yang bertujuan untuk mengukur besarnya aset likuid apabila dibandingkan dengan keseluruhan aset yang dimiliki untuk memprediksi kebangkrutan. Rasio ini mewakili dari rasio-rasio likuiditas yang mana masuk dalam rasio lancar. Dimana rasio lancar (Current Ratio) menyatakan hubungan relatif antara aktiva lancar dengan kewajiban lancar.

$\mathrm{X}^{2}$ merupakan hasil bagi dari Rentained Earnings dan Total Assets, rasio ini berguna untuk mengukur apakah laba secara kumulatif mampu untuk mengimbangi jumlah asset. Rasio ini menunjukkan kemampuan perusahaan dalam menghasilkan laba ditahan dari total aktiva perusahaan. Laba ditahan merupakan laba yang tidak dibagikan kepada para pemegang saham.

$\mathrm{X}^{3}$ adalah hasil bagi dari Earning Before Interest And Taxes dan Total Assets, rasio yang berguna untuk mengukur profitabilitas suatu bisnis tanpa memandang seberapa besar utang dari perusahaan. Rasio ini mewakili rasio profitabilitas. Rasio ini pula merupakan rasio untuk memperlihatkan apakah 
perusahaan menghasilkan volume bisnis yang cukup dibandingkan sebelum pajak dalam total aktivanya. Rasio ini mencerminkan efesiensi manajemen dalam menggunakan keseluruhan aktiva perusahaan untuk menghasilkan penjualan dan mendapatkan laba.
$\mathrm{X}^{4}$ yaitu hasil bagi dari Book Value Of Equity dan Book Value Of Total Debt, rasio ini berguna untuk mengukur tingkat leverage dari suatu perusahaan. Dimana rasio ini digunakan untuk mengukur tingkat pengelolaan sumber dana perusahaan.

Tabel-2. Variabel Finansial Pembentuk Z-Score Modifikasi

\begin{tabular}{|c|c|c|c|c|c|c|c|c|c|c|}
\hline \multirow{2}{*}{$\begin{array}{c}\text { DESCRIP } \\
\text { TION }\end{array}$} & \multicolumn{10}{|c|}{ Tahun } \\
\hline & 2009 & 2010 & 2011 & 2012 & 2013 & 2014 & 2015 & 2016 & 2017 & 2018 \\
\hline $\begin{array}{l}\text { Working } \\
\text { Capital }\end{array}$ & 198.788 & 103.031 & 136.399 & 105.901 & 335.841 & 253.457 & 600.291 & 570.495 & 512.271 & 445.502 \\
\hline $\begin{array}{l}\text { Total } \\
\text { Assets }\end{array}$ & 1.406 .978 & 1.367 .942 & 1.453 .141 & 1.432 .284 & 1.596 .735 & 1.810 .441 & 2.487 .618 & 2.656 .070 & 2.506 .050 & 2.692 .456 \\
\hline $\mathrm{X} 1$ & 0,141 & 0,075 & 0,094 & 0,074 & 0,210 & 0,140 & 0,241 & 0,215 & 0,204 & 0,165 \\
\hline $\begin{array}{l}\text { Rentained } \\
\text { Earnings }\end{array}$ & - & 269.786 & 258.021 & 228.601 & - 154.568 & 12.991 & 118.687 & 114.286 & - 104.175 & - 104.175 \\
\hline $\begin{array}{l}\text { Total } \\
\text { Assets }\end{array}$ & 1.406 .978 & 1.367 .942 & 1.453 .141 & 1.432 .284 & 1.596 .735 & 1.810 .441 & 2.487 .618 & 2.656 .070 & 2.506 .050 & 2.692 .456 \\
\hline $\mathrm{X} 2$ & 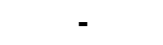 & - $\quad \mathbf{0 , 1 9 7}$ & 0,178 & 0,160 & 0,097 & 0,007 & 0,048 & 0,043 & 0,042 & $\mathbf{0 , 0 3 9}$ \\
\hline BIT & 66.763 & 30.699 & 30.120 & 75.151 & 177.804 & 91.161 & 63.997 & 48.875 & 98.206 & 107.670 \\
\hline $\begin{array}{l}\text { Total } \\
\text { Assets }\end{array}$ & 1.406 .978 & 1.367 .942 & 1.453 .141 & 1.432 .284 & 1.596 .735 & 1.810 .441 & 2.487 .618 & 2.656 .070 & 2.506 .050 & 2.692 .456 \\
\hline X3 & 0,047 & $\mathbf{0 , 0 2 2}$ & $\mathbf{0 , 0 2 1}$ & 005 & 0,111 & $\mathbf{0 , 0 5 0}$ & & & & 0,040 \\
\hline $\mathrm{VE}$ & 7 & 79 & 5. & $855^{\circ}$ & 927.916 & 967.413 & 1.686 & 1.731 & 1.760 .159 & 1.793 .023 \\
\hline $\begin{array}{l}\text { BVL } \\
\mathbf{X 4}\end{array}$ & $\begin{array}{c}642.716 \\
\mathbf{1 , 1 8 8}\end{array}$ & $\begin{array}{c}572.653 \\
\mathbf{1 , 3 8 7}\end{array}$ & $\begin{array}{c}650.033 \\
\mathbf{1 , 2 3 5}\end{array}$ & $\begin{array}{c}576.480 \\
\mathbf{1 , 4 8 4}\end{array}$ & $\begin{array}{c}649.515 \\
\mathbf{1 , 4 2 9}\end{array}$ & $\begin{array}{c}806.258 \\
\mathbf{1 , 2 0 0}\end{array}$ & $\begin{array}{c}763.272 \\
\mathbf{2 , 2 0 9}\end{array}$ & $\begin{array}{c}885.647 \\
\mathbf{1 , 9 5 5}\end{array}$ & $\begin{array}{c}745.890 \\
\mathbf{2 , 3 6 0}\end{array}$ & $\begin{array}{c}899.433 \\
\mathbf{1 , 9 9 4}\end{array}$ \\
\hline
\end{tabular}

\section{Model Springate}

Data finansial pada tabel-3 diambil dari laporan keuangan tahunan PT. Ratu Prabu Energi, Tbk. periode 2009 sampai dengan 2018 yang disampaikan dalam mata uang rupiah, untuk membentuk variabel nilai Springate terdiri dari Working Capital, Total Asset, Earning Before Interest And Taxes, Earning Before Taxes, Sales dan Current Liabilities.

Tabel-3. Data Finansial Pembentuk Variabel Nilai Springate Selama Periode 2009-2018

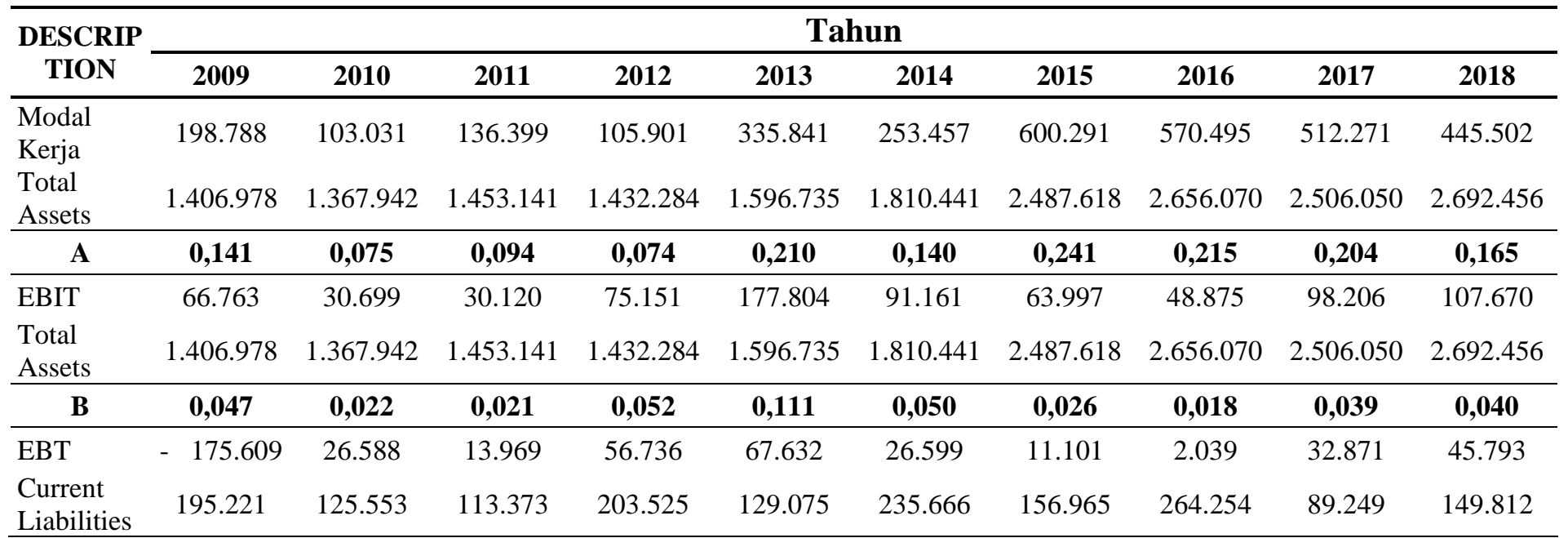




\begin{tabular}{|c|c|c|c|c|c|c|c|c|c|c|}
\hline $\mathrm{C}$ & 0,900 & 0,212 & 0,123 & 0,279 & 0,524 & 0,113 & 0,071 & 0,008 & 0,368 & 0,306 \\
\hline Sales & 483.122 & 335.114 & 309.745 & 449.486 & 404.543 & 357.567 & 225.794 & 210.141 & 249.769 & 305.302 \\
\hline $\begin{array}{l}\text { Total } \\
\text { Assets }\end{array}$ & 1.406 .978 & 1.367 .942 & 1.453 .141 & 1.432 .284 & 1.596 .735 & 1.810 .441 & 2.487 .618 & 2.656.070 & 2.506 .050 & 2.692 .456 \\
\hline D & 0,343 & 0,245 & 0,213 & 0,314 & 0,253 & 0,198 & 0,091 & 0,079 & 0,100 & 0,113 \\
\hline
\end{tabular}

Model Zmijewski

Tabel-4. Variabel Nilai Zmijewski Selamat Periode 2009-2018

\begin{tabular}{|c|c|c|c|c|c|c|c|c|c|c|}
\hline \multirow{2}{*}{$\begin{array}{l}\text { DESCRIP } \\
\text { TION }\end{array}$} & \multicolumn{10}{|c|}{ Tahun } \\
\hline & 2009 & 2010 & 2011 & 2012 & 2013 & 2014 & 2015 & 2016 & 2017 & 2018 \\
\hline ROA & $-0,13$ & 0,02 & 0,01 & 0,04 & 0,04 & $\mathbf{0 , 0 2}$ & 0,01 & $\mathbf{0 , 0 0}$ & 0,01 & 0,01 \\
\hline LEVERAGE & 0,46 & 0,42 & 0,45 & $\mathbf{0 , 4 0}$ & 0,41 & 0,45 & 0,31 & $\mathbf{0 , 3 3}$ & $\mathbf{0 , 3 0}$ & $\mathbf{0 , 3 3}$ \\
\hline LIKUIDITAS & 2,02 & 1,82 & 2,20 & 1,52 & 3,60 & 2,08 & 4,82 & 3,16 & 6,74 & 3,97 \\
\hline
\end{tabular}

Variabel nilai Zmijewski merupakan rasio-rasio keuangan yang sudah dihitung dari laporan keuangan PT. Ratu Prabu Energi, Tbk. periode tahun 2009 sampai dengan 2018, rasio-rasio untuk penilaian Zmijewski yaitu Return On Asset (ROA) sebagai rasio keuangan perusahaan yang terkait dengan potensi keuntungan untuk mengukur kekuatan perusahaan dalam membuahkan keuntungan atau juga laba pada tingkat pendapatan, aset dan juga modal saham spesifik.

Leverage merupakan rasio yang digunakan untuk mengukur seberapa besar aktiva yang dimiliki perusahaan berasal dari hutang atau modal, sehingga dengan rasio ini dapat diketahui posisi perusahaan dan kewajibannya yang bersifat tetap kepada pihak lain serta keseimbangan nilai aktiva tetap dengan modal yang ada.
Likuiditas adalah rasio yang menunjukkan kemampuan perusahaan dalam memenuhi kewajiban atau membayar utang jangka pendeknya, dalam rasio likuiditas akan diketahui sejauh mana aktiva lancar perusahaan dapat digunakan untuk menutupi kewajiban jangka pendek atau hutang lancar.

\section{Model Grover}

Model Grofer memiliki rasio hampir sama dengan model Altman Z-Score dan Zmijewski dilihat dari $\mathrm{X}^{1}$ yaitu hasil bagi dari Working Capital dan Total Assets, kemudian $\mathrm{X}^{2}$ merupakan hasil dari Earning Before Interest Taxes (EBIT) merupakan rasio yang sama dengan model Altman Z-Score. Untuk Return On Assets (ROA) sama halnya dengan rasio pada Zmijewski.

Tabel-5. Data Finansial Pembentuk Variabel Nilai Grover Selama Periode 2009-2018

\begin{tabular}{ccccccccccc}
\hline DESCRIP & \multicolumn{10}{c}{ Tahun } \\
\cline { 2 - 10 } TION & $\mathbf{2 0 0 9}$ & $\mathbf{2 0 1 0}$ & $\mathbf{2 0 1 1}$ & $\mathbf{2 0 1 2}$ & $\mathbf{2 0 1 3}$ & $\mathbf{2 0 1 4}$ & $\mathbf{2 0 1 5}$ & $\mathbf{2 0 1 6}$ & $\mathbf{2 0 1 7}$ & $\mathbf{2 0 1 8}$ \\
\hline $\begin{array}{c}\text { Working } \\
\text { Capital }\end{array}$ & 198.788 & 103.031 & 136.399 & 105.901 & 335.841 & 253.457 & 600.291 & 570.495 & 512.271 & 445.502 \\
Total & & & & & & & & & & \\
Assets & 1.406 .978 & 1.367 .942 & 1.453 .141 & 1.432 .284 & 1.596 .735 & 1.810 .441 & 2.487 .618 & 2.656 .070 & 2.506 .050 & 2.692 .456 \\
X1 & $\mathbf{0 , 1 4 1}$ & $\mathbf{0 , 0 7 5}$ & $\mathbf{0 , 0 9 4}$ & $\mathbf{0 , 0 7 4}$ & $\mathbf{0 , 2 1 0}$ & $\mathbf{0 , 1 4 0}$ & $\mathbf{0 , 2 4 1}$ & $\mathbf{0 , 2 1 5}$ & $\mathbf{0 , 2 0 4}$ & $\mathbf{0 , 1 6 5}$ \\
EBIT & 66.763 & 30.699 & 30.120 & 75.151 & 177.804 & 91.161 & 63.997 & 48.875 & 98.206 & 107.670 \\
\hline
\end{tabular}




\begin{tabular}{cccccc}
\hline Total & 1.406 .978 & 1.367 .942 & 1.453 .141 & 1.432 .284 \\
Assets & $\mathbf{0 , 0 4 7}$ & $\mathbf{0 , 0 2 2}$ & $\mathbf{0 , 0 2 1}$ & $\mathbf{0 , 0 5 2}$ & $\mathbf{0}$ \\
$\mathbf{X 2}$ & $\mathbf{0 , 0 4 1}$ & $\mathbf{0 , 0 3 6}$ & $\mathbf{0}$ \\
$\mathbf{R O A}$ & $\mathbf{- 0 , 1 2 8}$ & $\mathbf{0 , 0 2 0}$ & $\mathbf{0 , 0 0 8}$ & $\mathbf{0 , 0 3 6}$ \\
\hline \multicolumn{7}{c}{$\mathrm{X}^{1}$} & merupakan hasil dari nilai \\
& Working & Capital dibagi Total Asset yang \\
& bertujuan untuk mengukur besarnya aset \\
& likuid, rasio ini mewakili dari rasio-rasio \\
& likuiditas yang mana masuk dalam rasio \\
& lancar. Dimana rasio lancar (Current \\
& Ratio) menyatakan hubungan relatif \\
& antara aktiva lancar dengan kewajiban \\
& lancar. \\
& Xefore ${ }^{2}$ adalah hasil bagi dari Earning \\
& Assets, rasio yang berguna untuk \\
& mengukur profitabilitas suatu bisnis tanpa \\
& memandang seberapa besar utang dari \\
& perusahaan. Rasio ini pula merupakan \\
& rasio untuk memperlihatkan apakah \\
& perusahaan menghasilkan volume bisnis
\end{tabular}

\section{Tabel-6. Hasil Titik Cut Off Point Z-Score Modifikasi, Springate, Zmijewski dan Grover}

\begin{tabular}{ccccccccc}
\hline TAHUN & Z" & CUT OFF & S & CUT OFF & ZM & $\begin{array}{c}\text { CUT } \\
\text { OFF }\end{array}$ & G & CUT OFF \\
\hline $\mathbf{2 0 0 9}$ & 2,5 & Gray Zone & $-0,305$ & Distress Zone & -1 & Safe Zone & 0,45 & Safe Zone \\
$\mathbf{2 0 1 0}$ & 1,5 & Gray Zone & 0,318 & Distress Zone & -2 & Safe Zone & 0,26 & Safe Zone \\
$\mathbf{2 0 1 1}$ & 1,5 & Gray Zone & 0,266 & Distress Zone & -2 & Safe Zone & 0,28 & Safe Zone \\
$\mathbf{2 0 1 2}$ & 1,9 & Gray Zone & 0,392 & Distress Zone & -2 & Safe Zone & 0,36 & Safe Zone \\
$\mathbf{2 0 1 3}$ & 3,3 & Safe Zone & 0,678 & Distress Zone & -2 & Safe Zone & 0,78 & Safe Zone \\
$\mathbf{2 0 1 4}$ & 2,5 & Gray Zone & 0,304 & Distress Zone & -2 & Safe Zone & 0,46 & Safe Zone \\
$\mathbf{2 0 1 5}$ & 3,9 & Safe Zone & 0,335 & Distress Zone & -3 & Safe Zone & 0,54 & Safe Zone \\
$\mathbf{2 0 1 6}$ & 3,4 & Safe Zone & 0,260 & Distress Zone & -2 & Safe Zone & 0,47 & Safe Zone \\
$\mathbf{2 0 1 7}$ & 3,9 & Safe Zone & 0,498 & Distress Zone & -3 & Safe Zone & 0,53 & Safe Zone \\
$\mathbf{2 0 1 8}$ & 3,3 & Safe Zone & 0,423 & Distress Zone & -2 & Safe Zone & 0,47 & Safe Zone \\
\hline
\end{tabular}

Hasil dari analisis pada Tabel-6 dapat dilihat titik Cut Off pada Altman ZScore Modifikasi (Z") menunjukkan hasil yang berbeda pada tahun 2013 ke titik Safe Zone dari tahun-tahun sebelumnya yang berada di titik Gray Zone, namun ditahun 2014 kembali menurun dititik Gray Zone, kemudian melonjak naik kembali di titik Safe Zone hingga tahun 2018, meskipun tidak dipungkiri ada penurunan di tahun selanjutnya namun tidak sampai di titik Gray Zone.
Untuk hasil analisis perhitungan dengan model Springate (S), titik Cut Off menunjukkan perusahaan pada kondisi Distress Zone dari tahun 2009 sampai dengan 2018, meskipun berada pada posisi Distress Zone nilainya mengarah pada peningkatan dari tahun 2009 hingga 2013 dan berfluktuatif pada tahun-tahun berikutnya tapi masih di titik Cut Off Distress Zone. Dalam model Zmijewski (ZM) dan Grofer PT. Ratu Prabu Energi, 
Tbk. berada di titik Cut Off Safe Zone dari tahun 2009 sampai dengan 2018.

Dilihat dari hasil empat model kebangkrutan terdapat hasil yang berbeda-beda, meskipun ada sebagian di posisi Safe Zone namun bobot nilainya sangat kecil dan hampir mendekati Distress Zone, jadi perusahaan tampaknya memiliki kondisi keuangan yang kurang baik seperti yang ditunjukkan oleh rendahnya bobot nilai dari empat model kebangkrutan. Sejak awal kondisi ini sudah terlihat dari rasiorasio yang mewakili dalam setiap model kebangkrutan, kita lihat saja rasio Retained Earnings to Total Asset pada model Altman dari awal tahun 2009 sudah minus, ini menunjukkan perusahaan tidak memiliki kemampuan dalam menghasilkan laba atau sudah mengalami kerugian yang cukup lama.

Nilai rasio yang minus ini disebabkan dari akumulasi tahun-tahun sebelumnya, dilihat dari sejarah sebelum menjadi PT. Ratu Prabu Energi, Tbk. yang bergerak di sektor pertambangan perusahaan ini bernama PT. Arona Binasejati, Tbk. yang bergerak pada bidang furnitur, pada tahun 2006 PT. Arona Binasejati, Tbk. membukukan rugi bersih sekitar Rp. 8,8 triliun. Penurunan kinerja perseroan diakibatkan lesunya industri kayu dalam negeri dan kesulitan pasokan bahan baku karena illegal logging. PT. Arona Binasejati, Tbk. pula telah menutup pabriknya sejak tahun 2007 dan merumahkan karyawannya. Namun pada tahun 2008 PT. Arona Binasejati, Tbk. beralih sektor menjadi pertambangan dan mengganti nama menjadi PT. Ratu Prabu Energi, Tbk.

Walaupun rasio retained earning terhadap total aset negatif dari tahun ke tahun tetapi rasio ini menunjukkan kenaikan, yang berarti bahwa kemampuan perusahaan untuk menghasilkan laba ditahan dari total aktiva perusahaan terus mengalami kenaikan karena laba ditahan menunjuka beberapa banyak pendapatan perusahaan yang sebagian belum dibayarkan dalam bentuk dividen kepada para pemegang saham.

\section{Kesimpulan}

Pada penelitian ini, dapat disimpulkan bahwa dari empat model kebangrutan ini memberikan deviasi nilai yang cukup tinggi pada model Altman ZScore Modifikasi yang cukup tinggi daripada penggunaan model kebangkrutan Springate, Zmijewski dan Grofer dikarenakan model Altman ZScore memiliki tiga range untuk menentukan titik Cut Off Point yaitu Distress Zone, Gray Zone dan Safe Zone dimana apabila ada kondisi perusahaan berada dititik Gray Zone perusahaan bisa diibaratkan di titik lampu kuning, bisa survive menuju kearah lampu hijau atau ke zona sehat, bisa pula mengarah ke lampu merah atau zona kebangkrutan, bisa dikatakan Gray Zone merupakan zona warning pada perusahaan agar segera membenahi manajemen perusahaan.

Lain halnya dengan tiga model kebangkrutan Springate, Zmijewski dan Grofer hanya memiliki dua range untuk menentukan titik Cut Off Point yaitu Distress Zone dan Safe Zone. Jadi perusahaan langsung di prediksi bangkrut dan sehat saja.

\section{Saran}

Merekomendasikan perusahaan sebagai objek penelitian untuk segera membenahi manajemen, keuangan dan strategi perusahaan, terutama setelah penelitian ini mengindikasikan kondisi yang rawan dan menurun diakhir tahun 2018. Perusahaan perlu menghemat biaya, menegosiasikan upah dengan pekerja karena PT. Ratu Prabu Energi, Tbk. bergerak dibidang mining dimana perusahaan mining terkenal dengan upah yang tinggi dimana biaya operasional perusahaan mining sangat tinggi karena 
equipment dan consumables untuk kebutuhan perusahaan masih banyak yang diimpor dari luar negeri dan pembeliannya harus menggunakan dollar sedangkan rate dollar terhadap rupiah semakin hari semakin tinggi.

Dilihat dari prospek industri perusahaan jangka panjang masih sangat baik namun harus melakukan banyak langkah-langkah yang relevan untuk menyelesaikan masalah jangka pendek. Penulis menyadari bahwa hasil observasi ini dapat menyimpulkan kondisi perusahaan yang sebenarnya namun bisa juga tidak terjadi di tipe penelitian studi kasus di perusahaan lain, karena model kebakrutan ini masih berkembang, iklim ekonomi di setiap negara, sektor dan kondisi lainnya dapat mempengaruhi hasil yang berbeda maka dari itu penulis tidak dapat melakukan interfensi dan generalisasi untuk perusahaanperusahaan lainnya karena untuk mempresiksi kebangkrutan bukan saja menganalisis perusahaan dari laporan keuangannya saja, namun harus di analisis dari faktor internal dan eksternal perusahaan. Sejarah perusahaan, perkembangan pada sektor perusahaan, iklim perekenomian negara tempat perusahaan berada maupun peraturan pemerintah harus diperhatikan dalam menganalisis kebangkrutan.

\section{DAFTAR PUSTAKA}

Altman \& Hotchkiss. 2006. Corporate Financial Distress and Bankruptcy. Edisi Ketiga. Canada : John Wiley $\&$ Sons, Inc.

Desmond Wira. 2015. Analisis Fundamental Saham. Edisi Kedua. Jakarta : Exceed.

Damodaran, A. 1997. Corporate Finance and Theory Practic, John Wiley \& Son,. Inc.

Desmond Wira. 2015. Analisis Fundamental Saham. Edisi Kedua. Jakarta : Exceed.
Ehrhardt \& Brigham. 2011. Financial Management. Edisi Ketiga. Canada

: Nelson Education, Ltd.

Farid dan Susanto. 2011. Analisis Laporan Keuangan, Jakarta: Bumi Aksara.

Fahmi. 2011.Tujuan Laporan

Keuangan.Jakarta.Gramedia

Harahap, Sofyan Syafri. 2010. Analisa Kritis atas Laporan Keuangan. Cet 11. Jakarta : PT RajaGrafindo Persada.

Ikatan Akuntan Indonesia. 2009. Standar Akuntansi Keuangan Jakarta : Salemba.

Kasmir. 2011. Analisis Laporan Keuangan. Raja Grafindo Persada: Jakarta.

Mankiw, Quah \& Wilson. 2014. Pengantar Ekonomi Mikro. Edisi Asia. Jakarta : Salemba Empat.

Mankiw,N Greogory. 2008. Makroekonomi Edisi Ketujuh. Jakarta : Erlangga.

Sahala Manalu, Rony Joyo Negoro Octavianus, Galuh Safarina Sari

Kalmadara. 2017. Financial Distress Analysis With Altman ZScore Approach and Zmijewski XScore On Shipping Service Company. Journal of Applied Management. Volume 15. Number 4. December 2017.

Said Djamaluddin, Melati Juwita Putridan, Hapzi Ali. 2017. Financial Distress Comparative Analysis of Japanese Electronic Manufacturer after Financial Global Crisis 2008 Using Altman, Ohlson and Zmijewski Model. The International Journal of Business \& Management. Volume 5. Number 7. July 2017.

Sugito Wibowo. 2005. Kesulitan Keuangan Perusahaan (Konsepsi, Penyebab dan Upaya Penanggulangannya). Jurnal Akuntansi. Volume 5. Nomor 2. Mei 2005. 
https://www.indonesia-investments.com/ https://www.kompas.com/

https://www.bi.go.id/

https://www.rpenergi.com/

https://www.detik.com/ https://investasi.kontan.co.id/ https://www.esdm.go.id/

Peraturan Bank Indonesia Nomor 17/3/PBI/2015 